\title{
Comparative study of clinical grade human tolerogenic dendritic cells
}

\author{
M Naranjo-Gómez¹, D Raïch-Regué1, C Oñate', L Grau-López², C Ramo-Tello², R Pujol-Borrell', E Martínez-Cáceres ${ }^{1+}$ \\ and Francesc E Borràs ${ }^{1 *+}$
}

\begin{abstract}
Background: The use of tolerogenic DCs is a promising therapeutic strategy for transplantation and autoimmune disorders. Immunomodulatory DCs are primarily generated from monocytes (MDDCs) for in vitro experiments following protocols that fail to fulfil the strict regulatory rules of clinically applicable products. Here, we compared the efficacy of three different tolerance-inducing agents, dexamethasone, rapamycin and vitamin D3, on DC biology using GMP (Good Manufacturing Practice) or clinical grade reagents with the aim of defining their use for human cell therapy.
\end{abstract}

Methods: Tolerogenic MDDCs were generated by adding tolerogenic agents prior to the induction of maturation using TNF- $\alpha$, IL- $\beta$ and PGE2. We evaluated the effects of each agent on viability, efficiency of differentiation, phenotype, cytokine secretion and stability, the stimulatory capacity of tol-DCs and the T-cell profiles induced.

Results: Differences relevant to therapeutic applicability were observed with the cellular products that were obtained. VitD3-induced tol-DCs exhibited a slightly reduced viability and yield compared to Dexa-and Rapa-tolDCs. Phenotypically, while Dexa-and VitD3-tol-DCs were similar to immature DCs, Rapa-tol-DCs were not distinguishable from mature DCs. In addition, only Dexa-and moderately VitD3-tol-DCs exhibited IL-10 production. Interestingly, in all cases, the cytokine secretion profiles of tol-DCs were not modified by a subsequent TLR stimulation with LPS, indicating that all products had stable phenotypes. Functionally, clearly reduced alloantigen $T$ cell proliferation was induced by tol-DCs obtained using any of these agent. Also, total interferon-gamma (IFN- $\gamma$ ) secretion by T cells stimulated with allogeneic tol-DCs was reduced in all three cases, but only T cells co-cultured with Rapa-tol-DCs showed impaired intracellular IFN- $\gamma$ production. In addition, Rapa-DCs promoted CD4+ CD127 low/negative CD25high and Foxp3+ T cells.

Conclusions: Our results demonstrate contrasting influences of different clinical-grade pharmacological agents on human tol-DC generation. This should be taken into account for decisions on the use of a specific agent for the appropriate cellular therapy in the context of a particular disease.

\section{Background}

Autoimmune diseases are characterized by the loss of tolerance toward self-antigens and the induction of destructive immune responses leading to tissue damage. Most patients with autoimmune diseases are treated with immunosuppressive drugs that induce a generalized

\footnotetext{
* Correspondence: feborras@igtp.cat

† Contributed equally

${ }^{1}$ Laboratory of Immunobiology for Research and Diagnosis (LIRAD). Blood and Tissue Bank (BTB); Dept. of Cell Biology, Physiology and Immunology, Universitat Autònoma de Barcelona, Institut Investigació Germans Trias i Pujol, Spain

Full list of author information is available at the end of the article
}

immune suppression, which increases the risk of infectious diseases and cancer [1]. Thus, induction of tolerance is an important goal for treating autoimmune disorders or to prevent undesirable immune responses against allogeneic transplants [2-8].

Research in recent years has primarily focused on developing more selective immunosuppressive or immunomodulatory therapies with fewer side effects and with the potential for long-term disease remission. In this context, the use of antigen-specific tolerogenic dendritic cells (tol-DCs) that target autoreactive $\mathrm{T}$ cells is an attractive strategy, with the aim of reprogramming the

\section{Biomed Central}


immune system for the treatment of autoimmune disorders [9-11].

Dendritic cells (DCs) are professional antigen-presenting cells that have the potential to either stimulate or inhibit immune responses [12-15]. Their broad range of powerful immune stimulatory and regulatory functions has placed DCs at centre stage of active immunotherapy [16-23]. Dendritic cells maintain immune tolerance to self-antigens by deleting or controlling the pathogenicity of autoreactive T-cells. Modifications of DCs in the laboratory can enhance and stabilise their tolerogenic properties, and several pharmacological agents, such as dexamethasone (Dexa), rapamycin (Rapa) and vitamin D3 (VitD3), may promote the tolerogenic activities of DCs $[24,25]$. It has been widely reported that such maturation-resistant DCs can regulate autoreactive or alloreactive $\mathrm{T}$-cell responses and promote or restore antigen-specific tolerance in experimental animal models [26-36].

Yet, the current challenge is to move tol-DCs from the bench to the bedside [37-41], and one of the major tasks is to translate laboratory protocols into clinically-applicable procedures. Currently, information on different tolerogenic cellular products can be found at the research level. Therefore, a systematic comparison of the required functional characteristics of the various clinical tolerogenic DCs is necessary.

In this study, we compared the effects of three immunomodulatory agents: Dexa, Rapa and VitD3, on tolDCs generation using clinical grade reagents. We describe both the convenient and inconvenient aspects of each different "tolerogenic cellular products" to induce tolerance and discuss the eligibility of each cellular product for particular therapeutic scenarios.

\section{Methods}

\section{Culture Media and reagents}

Culture medium used was X-VIVO 15 (BioWhittaker ${ }^{\circledR}$, Lonza, Belgium) supplemented with $2 \%$ (vol/vol) heatinactivated $A B$ human serum (BioWhittaker ${ }^{\circledR}$, Lonza, Belgium), 2 mM L-glutamine (Sigma-Aldrich Company LTD, Saint Louis, MO, USA), $100 \mathrm{U} / \mathrm{mL}$ penicillin (Cepa S.L, Madrid, Spain), and $100 \mu \mathrm{g} / \mathrm{mL}$ streptomycin (Laboratorios Normon S.A, Madrid, Spain).

\section{Monoclonal Antibodies}

The following murine mAbs were used. FITC-labelled mAbs: CD86 and Foxp3 (BD Biosciences, CA, USA); PE-labelled mAbs: CD14 (ImmunoTools GmbH, Germany), CD40 and CD127 (BD Biosciences); PerCPlabelled mAb: CD3 (BD Biosciences); PE-Cyanine dye 5labelled mAb: CD25 (BD Biosciences); PE-Cyanine dye 7-labelled mAb: CD14 (BD Biosciences); Allophycocyanin (APC)-labelled mAbs: CD83, CD4 and anti-IFN- $\gamma$
(BD Biosciences); APC-H7-labelled mAb: HLA-DR (BD Biosciences).

\section{Immunostaining and flow cytometry}

Cells were washed, resuspended in $50 \mu \mathrm{l}$ of PBS and incubated with mAbs for 15-18 minutes at room temperature (RT). After washing, acquisition used a FacsCanto II flow cytometer with Standard FacsDiva software (BD Biosciences). Subsequent analyses used FlowJo software (Tree Star, Inc, OR, USA). Samples were gated using forward (FSC) and side (SSC) scatter to exclude dead cells and debris.

\section{Cell Isolation}

Buffy coats, provided by our Blood Bank department, were obtained from healthy blood donors following the institutional Standard Operating Procedures for blood donation and processing. Peripheral Blood Mononuclear Cells (PBMCs) were isolated by Ficoll-Paque (Lymphoprep, Axis Shield, Oslo, Norway) density gradient centrifugation at $400 \times \mathrm{g}$ for $25 \mathrm{~min}$. Recovered cells were washed twice in PBS and counted using Perfect Count microspheres (Cytognos SL, Salamanca, Spain) following the manufacturer's instructions. The Ethical Committee of Germans Trias i Pujol Hospital approved the study, and all subjects gave their informed consent according to the Declaration of Helsinki (BMJ 1991; 302: 1994).

\section{Establishing Monocyte-derived DCs}

PBMCs were depleted of CD3+ T cells using a RosetteSep $^{\text {TM }}$ Human CD3 Depletion Cocktail (StemCell Technologies, Seattle, WA, USA). Monocytes were obtained by positive selection using an EasySep ${ }^{\circledR}$ Human CD14 Positive Selection Kit (StemCell Technologies, Seattle, WA, USA). For all samples, the purity and viability of the monocyte populations were greater than $95 \%$ and $90 \%$ respectively, as assessed by the expression of specific markers and Annexin $\mathrm{V}+$ and 7-Amino-actinomycin $\mathrm{D}$ (7AAD) labelling (BD Biosciences).

Monocytes were cultured at $1-1.1 \times 10^{6} / \mathrm{ml}$ for 6 days in cGMP-grade XVIVO15 containing penicillin (100 U/ $\mathrm{ml})$ and streptomycin $(100 \mu \mathrm{g} / \mathrm{ml})$ in the presence of clinical-grade granulocyte-macrophage colony-stimulating factor (GM-CSF: $1000 \mathrm{U} / \mathrm{ml}$; CellGenix, Freiburg, Germany) and interleukin 4 (IL-4: 1000 U/ml; CellGenix, Freiburg, Germany). Cells were replenished on day 2 with a half volume of fresh medium and cytokines, and complete fresh medium and cytokines on day 4. To induce mature DCs (Mat-DCs), DCs were treated with a cGMP-grade cytokines cocktail: TNF- $\alpha$ (1000 U/ $\mathrm{mL})$ and IL- $\beta$ (10 ng/mL) (both from CellGenix); and PGE2 (1 $\mu \mathrm{M})$ (Pfizer, New York, USA) on day 4. TolDCs were established by treatment with either Dexa (1 $\mu \mathrm{M}$, Fortecortín, Merck Farma y Química, S.L, Spain), 
Rapa (10 nM, Rapamune, Wyeth Farma S.A, Spain) on days 2 and 4, or VitD3 (1 nM, Calcijex, Abbott) on days 0 and 4. Tol-DCs were stimulated as mature DCs at day 4 with the cytokine cocktail. On day 6, DCs were harvested and washed extensively twice before functional assays were performed.

\section{Allostimulatory assays}

PBMCs were labelled with CFSE and plated $\left(10^{5}\right.$ cells/ well) in 96-well round-bottom plates. Mononuclear cells were co-cultured for 6 days with MDDCs at a 1:20 ratio (DC: PBMC). Cell proliferation was determined by the sequential loss of CFSE fluorescence of CD3 positive cells, as detected by flow cytometry.

\section{Intracellular cytokine staining}

Mononuclear cells isolated from healthy donors were seeded in 96-well round bottom plates (Nunc) at a density of $1 \times 10^{5}$ cells/well and stimulated for 6 days with allogeneic DCs $\left(5 \times 10^{3} \mathrm{DC} /\right.$ well $)$. Then, total cells were stimulated with $50 \mathrm{ng} / \mathrm{mL}$ phorbol 12-myristate 13-acetate (PMA, Sigma) plus $500 \mathrm{ng} / \mathrm{mL}$ ionomycin (Sigma) for $5 \mathrm{~h}$ in the presence of $10 \mu \mathrm{g} / \mathrm{ml}$ brefeldin A (Sigma). After stimulation, cells were washed with PBS and stained for $18 \mathrm{~min}$ at RT with PerCP-conjugated antihuman $\mathrm{CD} 3 \mathrm{mAb}$ (BD Biosciences). Cells were then washed, fixed and permeabilised using an IntraStain kit (Dako) and incubated for $28 \mathrm{~min}$ at RT with antihuman IFN $\gamma$ APC mAb (eBioscience). Cells were washed and analysed with a BD-FACScanto II flow cytometer equipped with FACSDiva software (Becton-Dickinson).

\section{Measurements of cytokine production}

Interleukin 10 (IL-10), IL-12p70 and IL-23 were determined in supernatants of activated DCs using MILLIPLEX Multi-Analyte Profiling (MAP; Millipore Corporate Headquarters, MA, USA) following the manufacturer's instructions. These supernatants were collected after $48 \mathrm{~h}$ upon maturation and also after strong TLR (LPS: $100 \mathrm{ng} / \mathrm{mL}$ from E. Coli 0111:B4, Sigma. Reference: L4391) re-stimulation for $24 \mathrm{~h}$ and analysed for the presence of the indicated cytokines.

Supernatants from allogeneic co-cultures were collected after 6 days, stored at $-20^{\circ} \mathrm{C}$, and analyzed by MILLIPLEX Multi-Analyte Profiling (IL-10) and ELISA (TGF $\beta$, eBioscience).

\section{Determination of CD4+ CD127 low/negative CD25high and Foxp3+ T cells}

CD3+ T lymphocytes were purified from mononuclear cells by negative selection using an EasySep ${ }^{\circledR}$ Human $\mathrm{T}$ Cell Enrichment Kit (StemCell Technologies) following the manufacturer's instructions. Purity was $>95 \%$ in all experiments. Enriched T cells were plated $\left(10^{5}\right.$ cells/ well) in 96-well round-bottom plates. After 6 days of co-culture (1DC:20T), we used flow cytometry to determine the percentages of Tregs defined as CD4+, $\mathrm{CD} 127^{\text {low/negative }}, \mathrm{CD} 25^{\text {high }}$ and intracellular Foxp3+, as previously reported [42] (Human Regulatory T Cell Staining Kit; eBioscience, San Diego, CA, USA).

\section{Statistical analyses}

Results are given as means \pm standard deviations (SD) for $\mathrm{n}$ samples per group. Results are the means of at least 5 replicates for each experiment. Comparisons used either parametric paired $\mathrm{t}$-tests or non-parametric Wilcoxon tests, as appropriate. A p-value $\leq 0.05$ was considered statistically significant. Prism software (GraphPad v4.00 software. CA, USA) was used for statistical analysis.

\section{Results}

\section{Dexa, Rapa and VitD3 generate tol-DCs under GMP} conditions

Most clinical studies use MDDCs to obtain adequate numbers of cells to warrant clinical doses for patients. We first evaluated the viabilities and yields of the differentiation processes using parallel conditions for the same individual for each of 5 different donors. In order to establish a common, objective baseline for comparative purposes, dose-dependent experiments were set up to obtain the optimal concentration of each immunomodulatory agent that induced an arbitrary 50\% reduction of allostimulatory capacity compared to mature DCs (similar to immature DCs) with high viability ( $\geq 85 \%$ viable cells) (additional file 1:, Figure S1). Rapa-and VitD3-tol-DCs exhibited 50-70\% reductions of T proliferation at $10 \mathrm{nM}$ and $1 \mathrm{nM}$, respectively, while Dexa required a concentration 100-1000 times higher $(1 \mu \mathrm{M})$ to achieve similar results. These criteria allowed us to evaluate equivalent tolerogenic products using the following final concentrations: $1 \mu \mathrm{M}$ Dexa, $10 \mathrm{nM}$ Rapa and $1 \mathrm{nM}$ VitD3.

Simultaneous staining of cells with PE-annexin V and with the non-vital dye 7AAD was used to discriminate viable cells (Figure 1A). These results showed that, compared to mature DCs, only VitD3 treatment slightly reduced the cell viability $(80 \pm 13 \%$ vs. $87 \pm 11 \%$ of mature DCs, $\mathrm{p}=0.01$, paired t-test; Figure $1 \mathrm{~B}$ ) and yield of DCs $(45 \pm 17 \%$ vs. $70 \pm 19 \%, p=0.0071$, paired t-test; Figure $1 \mathrm{C})(\mathrm{n}=5)$. Treatment with Dexa and Rapa did not affect these outcomes (viability: $89 \pm 6 \%$ and $90 \pm 8 \%$ and yield: $60 \pm 23 \%$ and $83 \pm 16 \%$; respectively, $\mathrm{n}=5$ ).

\section{Dexa-and Vit D3-tol-DC phenotypes change and produce IL-10}

The tolerogenic functions of DCs may depend on their maturation stage and their anti-inflammatory profile. 


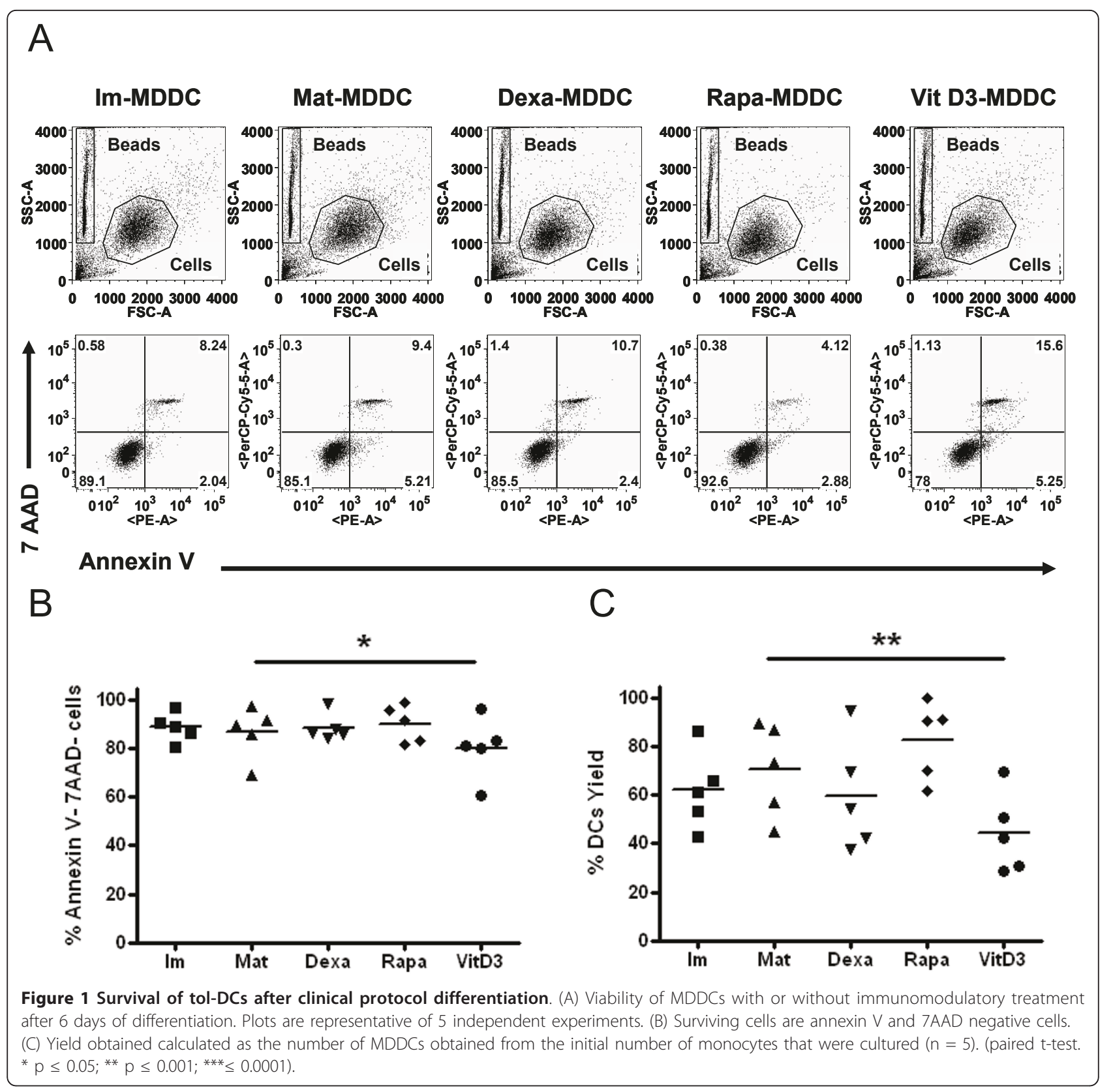

Thus, in our initial studies, we investigated the surface phenotypes and cytokine milieus of tol-DCs obtained using the 3 different immunomodulatory agents.

After 6 days of differentiation, immature DCs (ImDCs) expressed low surface levels of MHC II and co-stimulatory molecules (CD86 and CD83; $\mathrm{n}=15$ ) as compared with mature DCs (Mat-DCs) (Table 1 and Figures $2 \mathrm{~A}$ and $2 \mathrm{~B})$. Tol-DC generation in the presence of Dexa and VitD3 was associated with an immature phenotype as compared to Mat-DCs. This phenotypic impairment may affect the whole population or may be observed as a partial maturation induced in a relatively low
Table 1 Surface markers on tolerogenic DCs

\begin{tabular}{ccccc}
\hline & CD86 & CD83 & HLA-DR & $\mathbf{n}$ \\
\hline Im-DC & $15737 \pm 7681 * * *$ & $1316 \pm 673 * * *$ & $39405 \pm 33712 * *$ & 15 \\
Mat-DC & $22704 \pm 13632$ & $4371 \pm 3189$ & $70692 \pm 66038$ & 15 \\
Dexa-DC & $12291 \pm 11364 * * *$ & $2811 \pm 2343 *$ & $50928 \pm 62830$ & 11 \\
Rapa-DC & $23782 \pm 10961$ & $4785 \pm 2786$ & $75297 \pm 56014$ & 15 \\
VitD3-DC & $6398 \pm 6243 * *$ & $1941 \pm 3096 * *$ & $20851 \pm 38803 * *$ & 11
\end{tabular}

Surface markers expression was measured by flow cytometry on MDDC. Results are the averages \pm SDs of Mean Fluorescence Intensity (MFI) from different donors; $\mathrm{n}$ (number of samples). Mature DCs were used as a reference group for all comparisons. * $p \leq 0,05$; ${ }^{* *} p \leq 0,001$; ${ }^{* * *} p \leq 0,0001$ (paired $t$ test) indicating significant differences compared to MDDCs. 


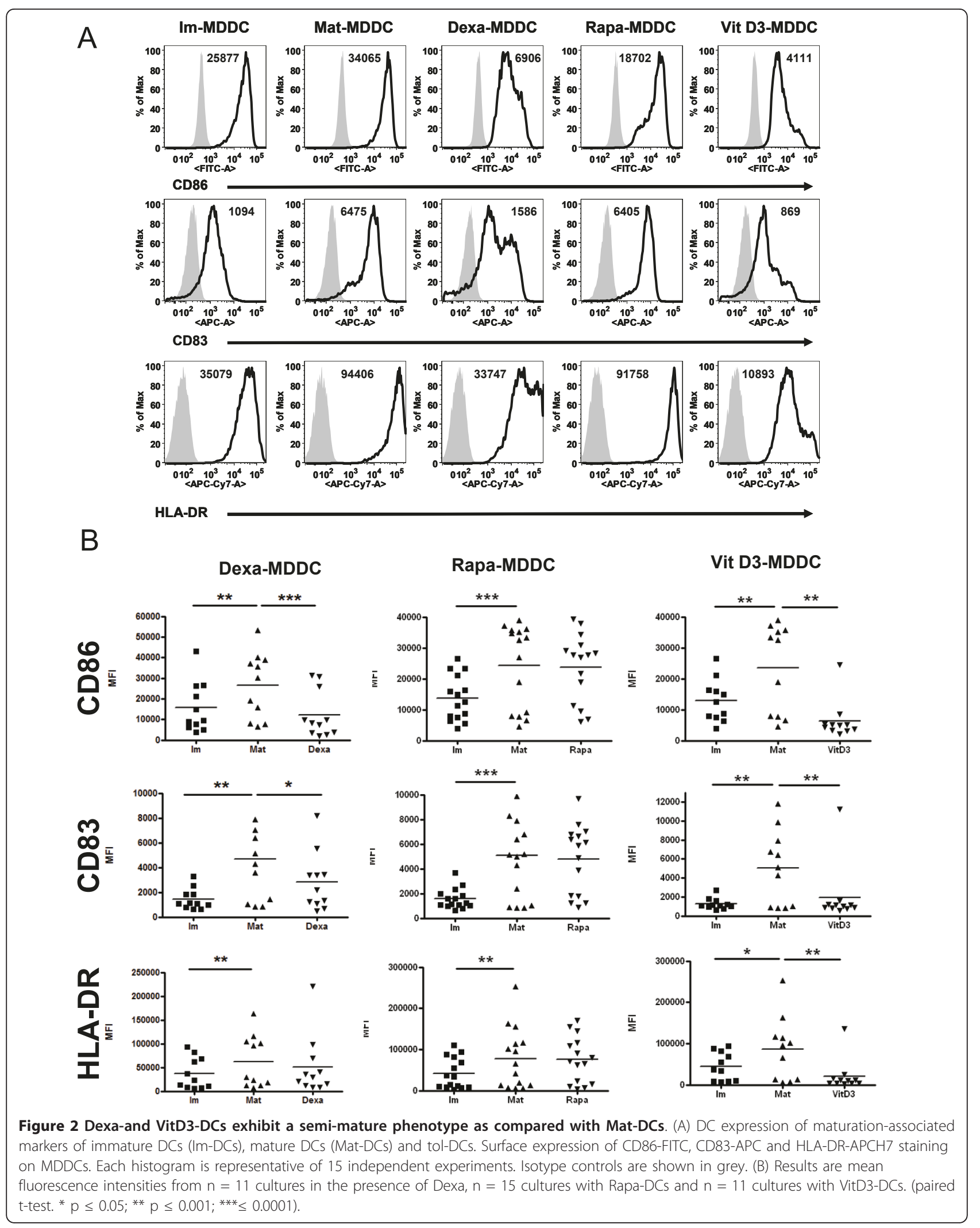


proportion of cells compared to the mature situation. The latter was often observed in most cases of our results. Indeed, in several experiments the percentage of cells with low CD83 and HLA DR levels ("semi-mature") was over $75 \%$. As our study aimed for the comparison of the populations obtained under different tolerogenic regimes, we considered that the analyses of the whole population would better reflect these comparisons. VitD3-DCs showed a significantly reduced expression of CD86, CD83 and HLA-DR ( $\mathrm{n}=11)$. Dexa-tol-DCs exhibited a similar pattern, although only CD86 and CD83 showed significantly reduced expression levels $(n=11)$. In contrast, Rapa-tol-DCs were not phenotypically different from MatDCs $(\mathrm{n}=15)$ (Table 1 and Figures $2 \mathrm{~A}$ and $2 \mathrm{~B})$.

In addition, we measured the secretion of IL-10 and IL-12p70 after $48 \mathrm{~h}$ upon maturation. We found IL-10 production in cultures with either Dexa or VitD3, but not with Rapa (Figure 3A). Of note, the production of IL-10 in the presence of dexamethasone was 6 times higher compared to mature DCs $(1305 \pm 846 \mathrm{pg} / \mathrm{mL}$ vs. $204.5 \pm 160.5 \mathrm{pg} / \mathrm{mL} ; \mathrm{p}=0.0135, \mathrm{n}=6$, paired t-test). Also, VitD3 tol-DCs produced slightly more IL-10 than mature cells $(243 \pm 272.9 \mathrm{pg} / \mathrm{mL}$ vs. $204.5 \pm 160.5 \mathrm{pg} /$ $\mathrm{mL}, \mathrm{n}=11$ ). In contrast, IL-12 was notably undetectable in all culture conditions (data not shown).

\section{Stability of Tol-DCs after restimulation with LPS}

To evaluate whether DCs were resistant to an exogenous maturation stimulus, tol-DC stability was investigated by culturing tol-DCs for $24 \mathrm{~h}$ in XVIVO medium containing LPS (without immunomodulatory agent). As shown in Figure 3B, tol-DCs were phenotypically refractory to secondary stimulation, and retained their typical cytokine profile of IL-10 production. Dexa tol-DCs restimulated with LPS produced 19 times more IL-10 than Dexa-DCs $(165.1 \pm 203.7 \mathrm{pg} / \mathrm{mL}$ vs. $3244 \pm 828.6 \mathrm{pg} /$ $\mathrm{mL}, \mathrm{p}=0.0046, \mathrm{n}=4$, paired t-test). Regarding VitD3DCs, LPS-restimulation did not greatly modified the IL10 production. Again, Rapa tol-DCs did not exhibit any IL-10 production.

Importantly, while primary stimulation of the DCs with this strong TLR4 ligand induced greater IL-23 production by immature DCs (10.86 \pm 6.5 fold increase), no increased IL-23 production was detected by tol-DCs in any culture condition (Dexa-DC: $1.11 \pm 0.46$; Rapa: 1.22 \pm 0.84; VitD3: $1.08 \pm 0.51$ fold changes), which supported a stable non-proinflamatory profile for tol-DCs. Mat-DC also showed some refractoriness to the ulterior stimulation with LPS, meaning there was a faint production of cytokines "de novo" as opposite to Im-DCs.

\section{DC-tols do not promote a Th1 profile}

To analyze the effect of the different tol-DCs, allostimulated $\mathrm{T}$ cells were further studied. An example of the proliferation of T cells allostimulated by tol-DCs is shown in Figure 4A. We have also summarized the relative results achieved using mature-DCs for different donors in Figure 4B. Of mention, we found that DexaDCs inhibited $\mathrm{T}$ cell proliferation only partially in some donors (4/12 subjects, data not shown).

To further investigate the effect of tol-DCs on T cells, we also determined whether inhibition of $\mathrm{T}$ cell proliferation was due to increased $\mathrm{T}$ cell apoptosis. We found that the reduced stimulation of $\mathrm{T}$ cell proliferation was not due to a reduction in cell viability induced by a particular type of tol-DC (\% of both Annexin V and 7AAD negative cells) of allostimulated T cells (Im: $61.76 \pm 9.28 \%$; Mat: $65.92 \pm$ 10.13\%; Dexa: $62.08 \pm 9.21 \%$; Rapa: $61.02 \pm 11.12 \%$ and VitD3: $60.43 \pm 11.72 \%$; $=4$ ) (Figure $4 \mathrm{C}$ ).

To gain some insight into the cytokines secreted by these responding $\mathrm{T}$ cells, CFSE ${ }^{\text {low }}$ alloproliferative $\mathrm{T}$ lymphocytes were re-stimulated with PMA + ionomycin and IFN- $\gamma$ production was measured by intracellular staining. These results confirmed a reduction of about $50-60 \%$ in IFN- $\gamma$ production relative to mature DCs for all conditions tested (Figures 5A and 5B: $50.18 \pm 16.65 \%$ IFN- $\gamma$ producing cells among $\mathrm{T}$ cells allostimulated by Dexa-DC, $\mathrm{p}=0,0093, \mathrm{n}=4$, paired t-test; $39.83 \pm$ $16.76 \%$ Rapa-DC, $\mathrm{p}<0,0001, \mathrm{n}=7$, paired t-test; and $37.97 \pm 44.08$ VitD3-DC, $\mathrm{p}=0,0098, \mathrm{n}=7$, paired $\mathrm{t}$ test). When only CFSE $^{\text {low }}$ proliferating $\mathrm{T}$ cells were analysed, Rapa-DCs stimulated $\mathrm{T}$ cells showed a significant decrease in IFN- $\gamma$ production relative to Mat-DCs (Figure $5 \mathrm{C}: 40.99 \pm 9.2 \%$ vs. $52.47 \pm 10.85 \%$ IFN- $\gamma$ among CFSE $^{\text {low }}$ CD3 + cells, $\mathrm{n}=7, \mathrm{p}=0,0057$, paired t-test). VitD3-DCs also suppressed IFN- $\gamma$ production in co-cultures with allogeneic mononuclear cells, but only in some donors and Dexa-DCs did not reduce the capability of responding $\mathrm{T}$ cells to produce IFN- $\gamma$ in any of the experiments.

In addition, we determined the production of IL-10 and TGF $\beta$ in the supernatants from T cells co-cultured with tol-DC. We could measure IL-10 production in allostimulated $\mathrm{T}$ cells by Dexa-DC in 3 of 4 donors. Interleukin 10 values obtained were $57.47 \pm 29.47 \mathrm{pg} /$ $\mathrm{mL}$ ( $\mathrm{T}$ cells + Dexa-DCs) compared to $33.37 \pm 2.66 \mathrm{pg} /$ $\mathrm{mL}$ ( $\mathrm{T}$ cells allostimulated with Mat-DCs). Conversely, we did not find major differences in $\mathrm{T}$ cells stimulated with Rapa-DC $(15.7 \pm 13.61 \mathrm{pg} / \mathrm{mL})$ or VitD3-DC (38.7 $\pm 7.28 \mathrm{pg} / \mathrm{mL})$ compared to mature DCs $(\mathrm{n}=3)$. Regarding TGF $\beta$, all the measures were below the limit of detection of the assay $(60 \mathrm{pg} / \mathrm{mL})$ in the different stimulatory conditions analyzed.

Finally, the presence of Tregs cells defined as CD4+ CD127 low/negative CD25high and Foxp3+ as reported before (72) was estimated in these culture conditions. After one round of stimulation for 6 days, we analysed the induction of CD4+ Foxp3+ and CD2 $5^{\text {high }}, \mathrm{CD} 127^{\text {low/negative }}$ 


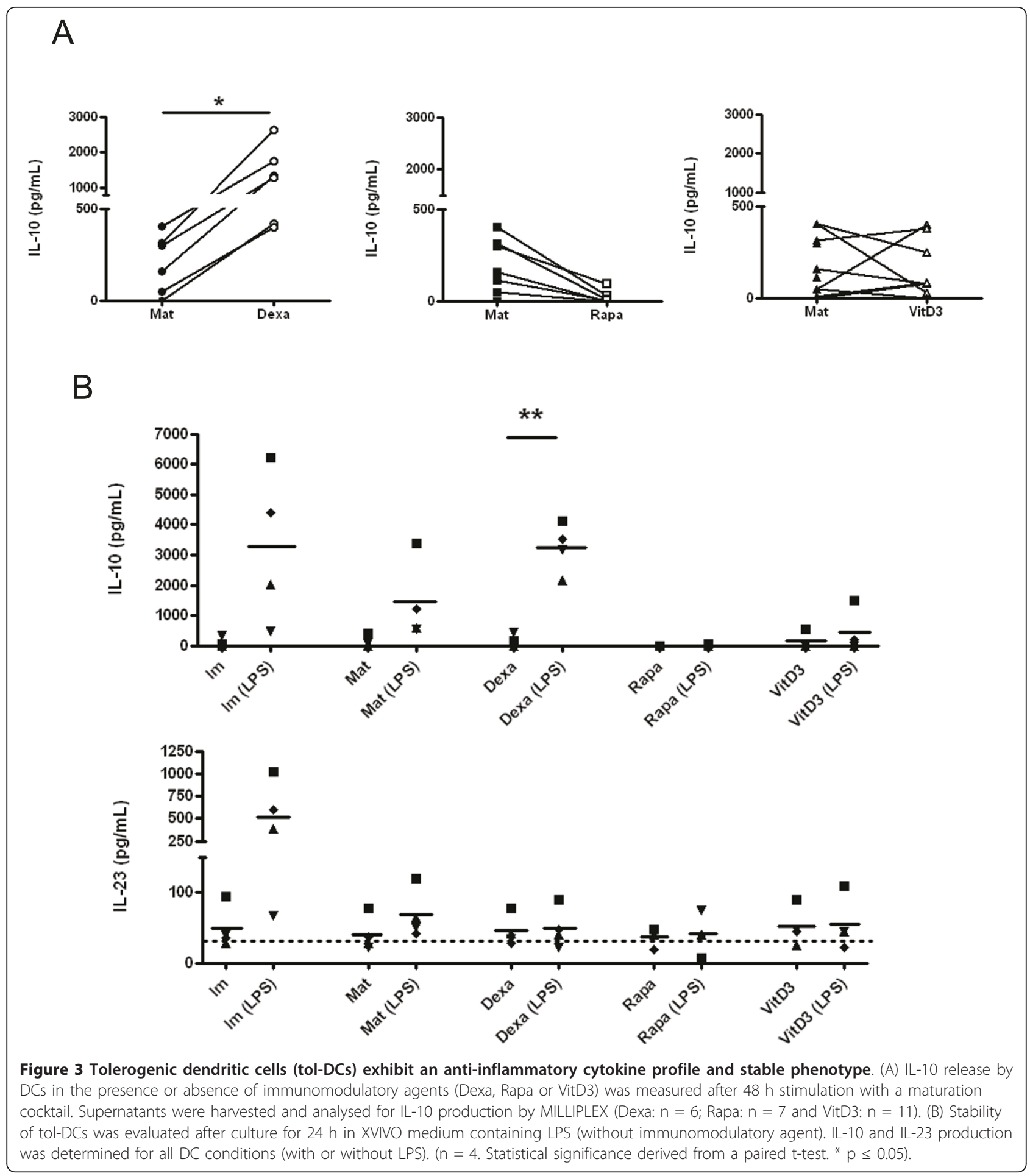

cells as shown in Figure 6A. Then, as depicted, only those $\mathrm{T}$ cells stimulated by Rapa-DCs showed a significantly increase of the percentages of CD4+ Foxp3+ and $\mathrm{CD} 25^{\text {high }}, \mathrm{CD} 127^{\text {low/negative }}$ cells $(5.4 \pm 1.9 \%$ vs. $3.5 \pm$ $1.7 \%$ with Mat-DCs, $\mathrm{p}=0.0211, \mathrm{n}=6$, paired $\mathrm{t}$ test) (Figure 6B).

\section{Discussion}

Induction of therapeutic tolerance is of increasing interest in autoimmunity, allograft rejection, allergy, asthma, and various forms of hypersensitivity. Because of their capacity to orchestrate immune responses, DCs can be used as therapeutic agents. The classical concept that 


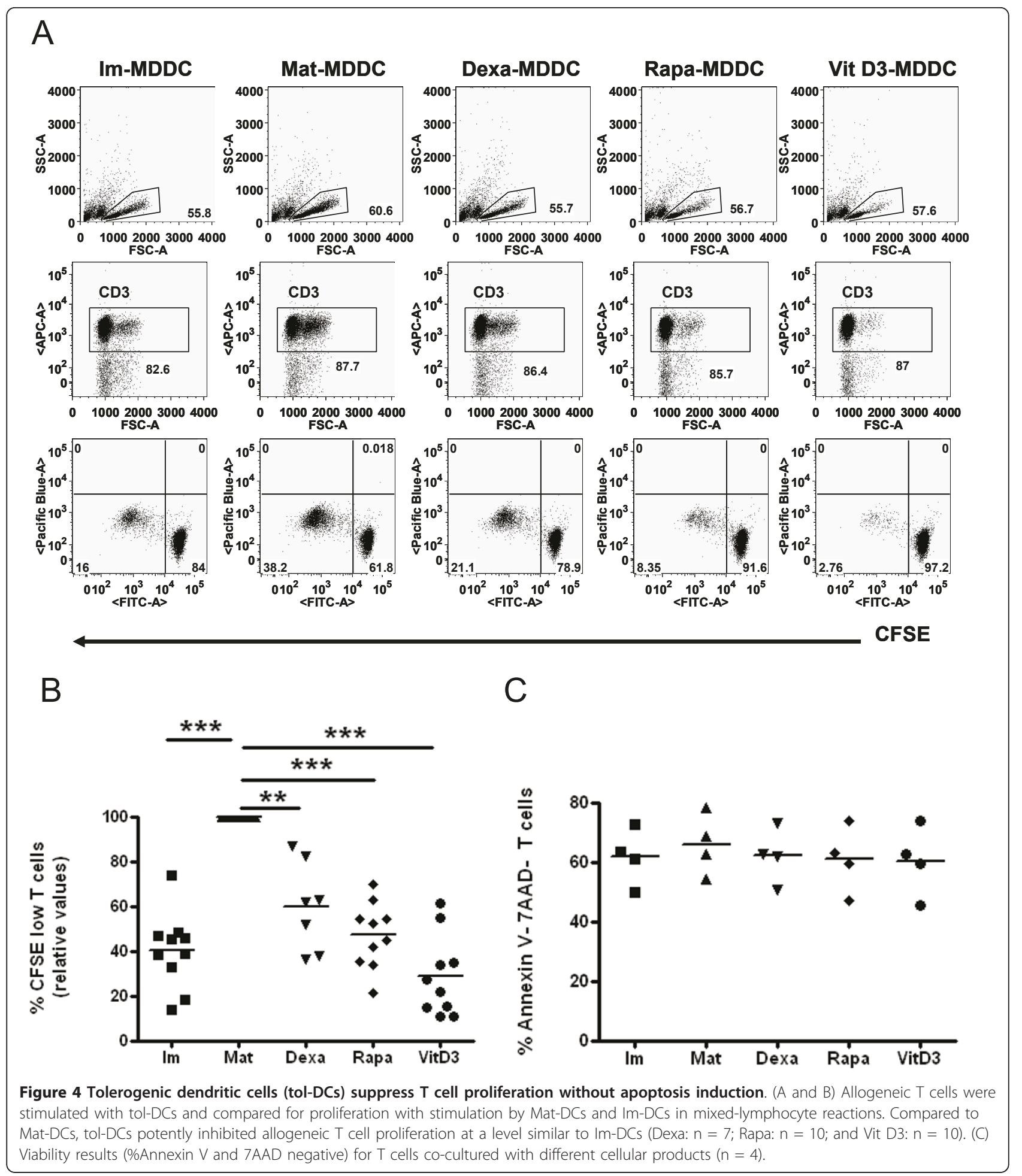

immature DCs induce tolerance and that mature DCs induce immune responses has changed completely, and several lines of evidence demonstrate that the maturation state of DCs does not always correlate with their tolerising or activating functions [43]. In this sense, the definition of tol-DCs must include a maturation-resistant cell that acts as "an immature DC" with a stable phenotype that is preserved, even in the presence of pro-inflammatory signals. This tolerogenic state of DCs can be induced using several pharmacological agents [44-46]. 

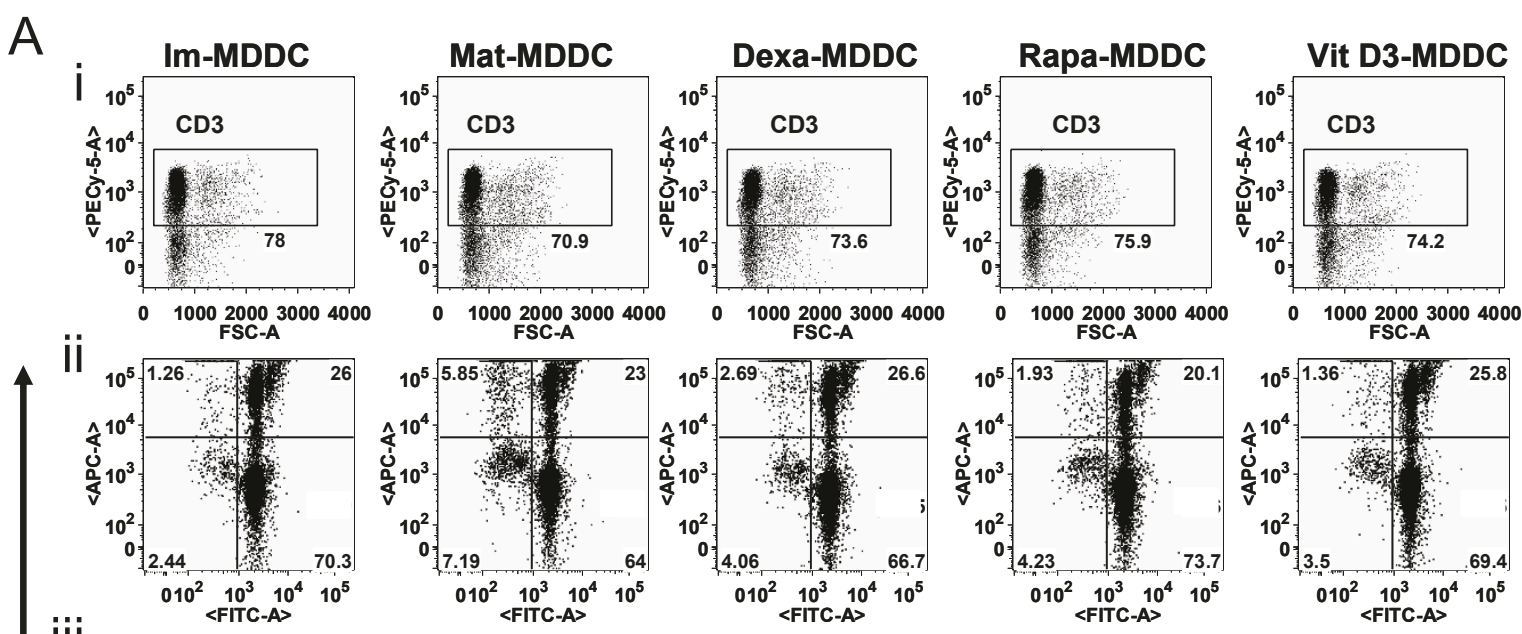

iii
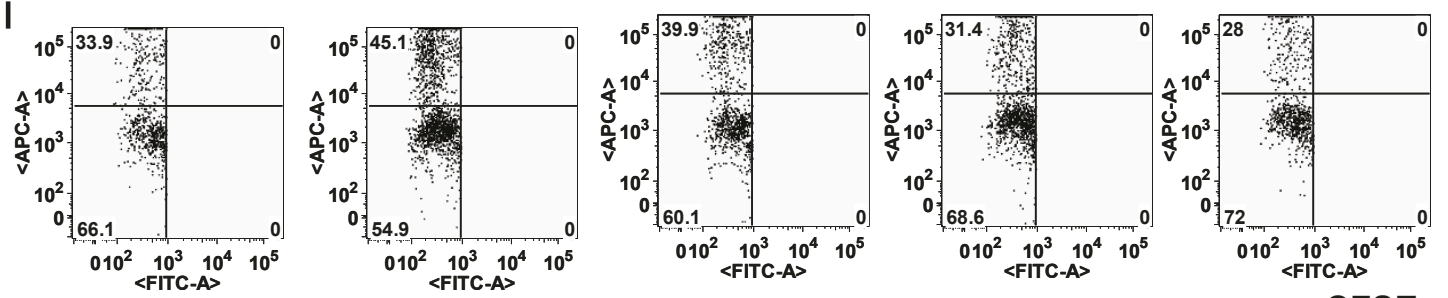

B

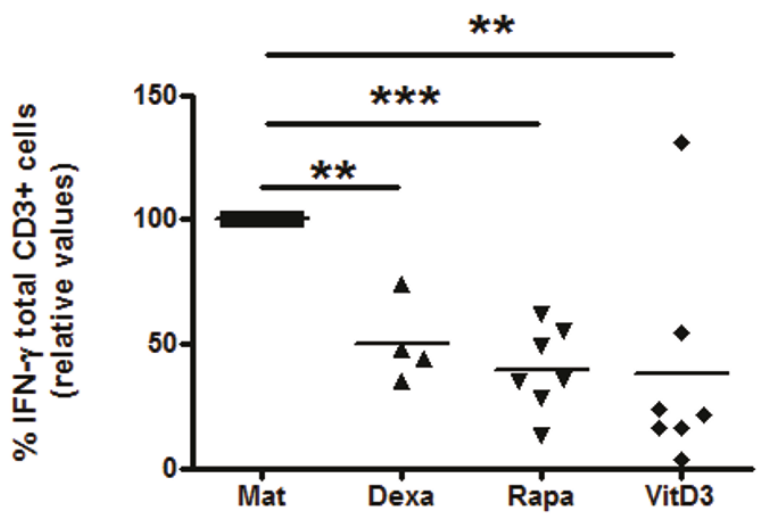

C
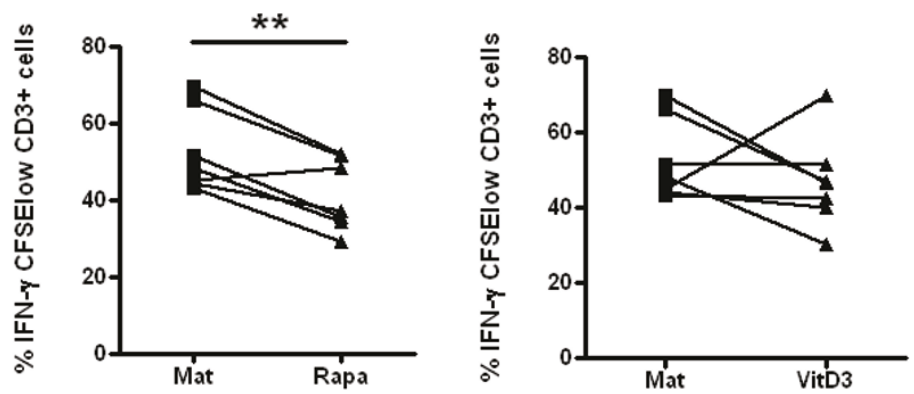

Figure 5 Decreased production and secretion of IFN- $\boldsymbol{\gamma}$ by T lymphocytes stimulated with tol-DCs. Proliferating T lymphocytes were obtained from allostimulatory cultures. The production of interferon (IFN)- $\gamma$ was measured by intracellular staining after restimulating the cells with PMA+lo in the presence of brefeldin for 5 h. (A) First row (i) shows gating CD3+ cells. The second row plots (ii) indicate the proportion of total IFN- $\gamma$ producing cells. Third row (iii) shows the percentages of cells that responded to allostimulation (CFSElow) and produced IFN- $\gamma$. The numbers inside the plots indicate the percentage of cells in each quadrant or boxes (a representative experiment). (B) Summary of the results of the total intracellular IFN- $\gamma$ (Upper Left, UL) production with Dexa- $(n=4)$, Rapa- $(n=7)$ and Vit D3 $(n=7)$ activated cultures relative to Mat-DCs (taken as $100 \%$ production). (C) Percentage of IFN- $\gamma$ producing T cells that responded to allostimulation (CFSElow CD3+ cells). Each symbol represents an individual sample. Significant differences are indicated $(* * p<0,001$; paired t-test). 


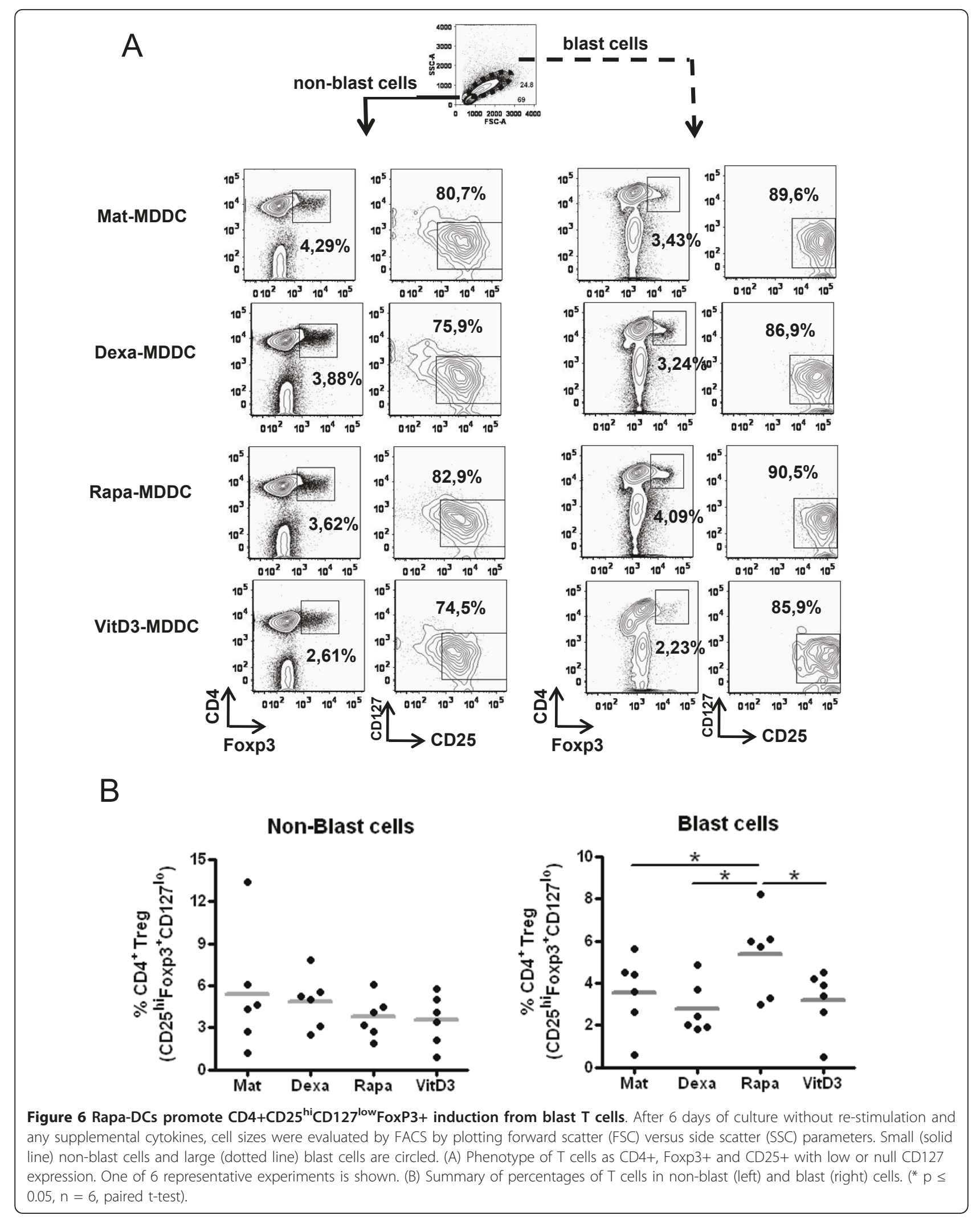


At present, scattered knowledge from different tolerogenic cellular products can be found. A better understanding of clinical grade cellular therapies may offer new opportunities for treating different disorders. However, several gaps in our knowledge remain to be filledin before a perfect tolerogenic DC (one best suited for targeting a particular process) may be envisaged. Thus, our work aimed to determine the capabilities of those GMP-grade immunosuppressive drugs (dexamethasone, rapamycin and vitamin D3) that are used to obtain tolDCs in comparative scenarios and identify the "array" of their individual characteristics, such as phenotypes, cytokine profiles, resistance to maturation, and T-cell profiles, in order to define the best DCs for a particular situation.

Hence, we report for the first time a comparative study of clinical-grade tolerogenic cellular products for therapeutic applications that fulfil the regulatory medical rules for human therapy. Our results show that all clinical-grade tol-DCs that were analysed function as "negative cellular vaccines," which are comparable to previously characterised research-grade tol-DCs [47]. In terms of viability, we observed that VitD3 had a slight tendency to promote DC apoptosis, in accordance with previous reports [48]. However, this minor reduction in cell viability does not compromise either DC functionality or the eventual use of these cells in therapy. Although apoptosis induction in DCs by pharmacological agents has been controversial, several reports demonstrated that Dexa did not induce cell death in MDDCs at any of the tested concentrations $[49,50]$. Also, use of Rapa for DC maturation did not increase apoptosis [51], in agreement with our results.

When analysing the phenotypes of the generated tolDCs, we observed that only Dexa-and VitD3-DCs had reduced classical markers of mature cells on their surfaces. However, Rapa-DCs did not show an immature phenotype, thus being characterized as "mature DCs" with respect to their exhibited phenotype. In this context, it is obvious that the definition of DC maturation using phenotype markers is not a distinguishing feature of immunogenicity nor tolerogenicity [40]. Thus, a set of "biomarkers" for tolerance induction in our cellular products have to be defined to better monitor the putative tolerogenic cells $[17,37]$, as phenotypic identification of tol-DCs may not be as accurate as expected. Ideally, quality controls for tol-DCs should be based on markers that are quickly and readily detectable and that are reliable.

From the cytokine profile results, Dexa-and moderately VitD3-derived DCs showed increased IL-10 production, whereas the secretion of IL-12p70 was not detected in all cases. It is well known that IL-10 blocks IL-12 synthesis by DCs, downregulates the expression of co-stimulatory molecules and potentiates their tolerogenicity [43,52]. This tolerogenic feature was not observed with Rapa-DCs, as was previously reported [53]. Most likely, DCs modified by Rapa use some other mechanism to induce tolerance, as discussed below.

Resistance to maturation is considered a prerequisite of tolerogenic potential for "negative cellular vaccines". Under the influence of inflammation, the administered immature DCs should potentially undergo maturation and lose their tolerogenic function. Thus, for good clinical applications, tol-DCs should show a stable immunosuppressive phenotype that will not be transformed to immunostimulatory DCs after injection into patients. In this context, several methods have been described for designing maturation-resistant DCs [54-57]. Our results show that Dexa-DCs, and to a lesser extent VitD3-DCs, exhibit a durable "immaturity," as high IL-10 production and no IL-12/IL-23 production was maintained upon subsequent TLR stimulation. In agreement with this, Xia et al. previously demonstrated that this tolerogenic product preserves this feature up to 5 days after removing Dexa [58]. As described in the literature, immature DCs undergo maturation and lose their tolerogenic functions. Interestingly, the cytokine profiles of the generated tol-DCs were not modified by a strong TLR stimulation, indicating that they maintained a stable profile.

Another functional property of tol-DCs is their decreased $\mathrm{T}$ cell-stimulatory capability. We further investigated the immunoregulatory capability of clinicalgrade tol-DCs using direct $\mathrm{T}$ cell activation in mixedlymphocyte reactions. Our results showed differential potentials for reducing proliferation: Rapa and VitD3 worked in the $\mathrm{nM}$ range, while Dexa required higher concentrations in the $\mu \mathrm{M}$ range. In fact, tolerogenic MDDCs conditioned with Dexa from $1 / 3$ of the individuals $(4 / 12)$ did not acquire regulatory properties at the concentration used, and even showed a "semi-mature" phenotype. In this regard, the possibility of combining Dexa with VitD3 to prevent de-sensitization of the DCs to the actions of Dexa has been reported [11]. Furthermore, both immunomodulatory agents used in combination inhibit DC maturation and function in an additive manner $[7,59,60]$.

In addition, total IFN- $\gamma$ production was significantly reduced when these $\mathrm{T}$ cells were stimulated by tol-DCs. To extend our analyses, we evaluated IFN- $\gamma$ in T cells that had responded to allostimulation and observed that IFN- $\gamma$ production was only reduced when Rapa-DCs were used as stimulators. This property in the deviation of Th differentiation was also observed previously by Monti P. et al [61].

It has been described that tolerogenic DCs induce immune tolerance through several pathways, including 
clonal T cell depletion or exhaustion, anergy, deviation of Th differentiation or generation of Tregs [15,62-68]. To deduce which mechanisms that tol-DCs might have exerted, the possibility of apoptosis induction was evaluated. However, we did not find any differences in cell death by allostimulated $\mathrm{T}$ cells, indicating that this mechanism was not acting in our cellular products. In contrast, it has been reported that Dexa-and VitD3-DCs induced a hyporesponsiveness as a strategy to dampen autoreactive responses [50], and our own observations (Raïch-Regué D. et al) support these results.

Finally, we tested for the induction of $\mathrm{CD} 4+\mathrm{CD} 25^{\mathrm{hi}} \mathrm{C}$ D127 ${ }^{\text {low } F o x P 3+~ T ~ c e l l s . ~ R e g u l a t o r y ~} \mathrm{~T}$ cells suppress the responses of alloreactive or self-reactive CD4+ T cells and are supposed to maintain immunologic self-tolerance or control autoimmunity [69-71]. Rapa-DC-primed $\mathrm{T}$ cells exhibited reduced alloproliferation along with a concomitant expansion of CD4+CD $25{ }^{\text {hi }} \mathrm{CD} 127^{\text {low }}$ FoxP3+ cells [72-74]. This effect may have been in response to the expression of high levels of CD86 and is consistent with previous reports that described that co-stimulation is required for induction and expansion of FoxP3+ Tregs $[53,75,76]$. In contrast, Dexa and VitD3 did not induce this phenotype on $\mathrm{T}$ cells. This discrepancy with the literature could be due to the particular experimental approaches. It is important to note that we analyzed these $\mathrm{T}$ cells in co-cultures of MDDCs with allogenic $\mathrm{T}$ cells for one round of stimulation. However, it has been demonstrated that VitD3-DCs convert naive T cells into Tregs after several rounds of priming and boosting [77]. Another possibility to explore was the presence of other CD4+ Treg subsets, including CD4+CD25-FoxP3-IL-10 producing Tr1 cells $[78,79]$ and transforming growth factor $-\beta(\mathrm{TGF}-\beta+)$ Th3 cells [80]. In this sense, our results show IL-10 production on $\mathrm{T}$ cells stimulated by Dexa-DCs but not TGF- $\beta$ in any of cultured conditions.

\section{Conclusions}

In summary, in these comparative analyses of clinical grade tol-DCs, Dexa-and VitD3-DCs exhibited a "semiimmature" phenotype and IL-10 secretion. In contrast, Rapa-DCs induced CD4+CD25 ${ }^{\text {hi }}$ CD $127{ }^{\text {low }}$ FoxP3+ and inhibited IFN- $\gamma$ secretion by allostimulated T cells. This comparative study emphasises the fact that a simple phenotypic determination of maturation markers does not guarantee a tolerogenic function and that a complete set of functional determinations is mandatory in order to clearly define a tolerogenic "functional" phenotype. This also stresses the necessity to define reliable biomarkers for applications in GMP labs. Finally, this may also help with decisions on which tolerogenic product will be the best for a particular situation. Phase I-II studies with quality control measures and appropriate clinical and immunological outcomes must be performed to evaluate potential tol-DC functions.

\section{Additional material}

Additional file 1: Figure S1-Dose-dependent experiments to
establish equivalent tol-DCs. Summary of the dose-dependent
experiments set up to obtain the optimal concentration of each
immunomodulatory agent. The results reflected the relative values of the
alloproliferation of T cells co-cultured with different tol-DCs (A: Dexa-DCs,
$n \geq 2 ; B$ : Rapa-DCs, $n=3 ; C$ : VitD3-DCs, $n=4$ ).

\section{List of abbreviations}

DC: dendritic cell; Dexa: dexamethasone; GMP: Good Manufacturing Practice; IFN- $\gamma$ : Interferon-gamma; lo: ionomycin; MDDC: Monocyte Derived DC; PBMCs: Peripheral Blood Mononuclear Cells; PMA: phorbol 12-myristate 13acetate; Rapa: rapamycin; tol-DC: tolerogenic DCs; Tregs: regulatory T cells; VitD3: vitamin D3.

\section{Acknowledgements and Funding}

The authors thank Marco Fernández for his helpful advice with flow cytometry experiments (Cytometry Unit of the IGTP). We also thank the researchers of the Advanced Therapies Division (Banc Sang i Teixits) for their continuous support. Grant Support: This work was supported, in part, by a grant from Fundació La Marató de TV3 (07/2410) and Fundació GAEM (to EMC). MNG is supported by a grant from the Spanish Ministry of Science and Innovation and Blood and Tissue Bank (PTQ-09-02-017050). DRR is a predoctoral fellow supported by project 07/2410 Fundació La Marató de TV3. LGL is supported by a Rio Hortega grant from Instituto de Salud Carlos III (ISCIII) Spanish Ministry of Health (CM07/00196). FEB is co-funded by the stabilization program of Biomedical researches (CES07/015) of the ISCIII and Direcció d' Estratègia i Coordinació, Health Dept. of Catalonia.

\section{Author details}

${ }^{1}$ Laboratory of Immunobiology for Research and Diagnosis (LIRAD). Blood and Tissue Bank (BTB); Dept. of Cell Biology, Physiology and Immunology, Universitat Autònoma de Barcelona, Institut Investigació Germans Trias i Pujol, Spain. ${ }^{2}$ Multiple Sclerosis Unit. Department of Neurosciences, Hospital Universitari Germans Trias i Pujol Badalona Barcelona. Spain.

\section{Authors' contributions}

MNG conceived and designed the study, performed most of the experiments and drafted the manuscript. DRR carried out the immunophenotyping and the determination of Tregs, participated in the design of the study and helped in writing the manuscript. CO contributed in cell culture techniques and analysed data. LGL participated in the statistical analysis and interpretation of data. CR participated in the analysis and revised the manuscript. RPB, head of the lab, critically revised the manuscript. EMC participated in the coordination of the study and helped to draft manuscript. FEB, author for correspondence, participated in the design of the study, supervised the research, and revised the manuscript. All authors read and approved the final manuscript.

\section{Competing interests}

The authors declare that they have no competing interests.

Received: 18 January 2011 Accepted: 9 June 2011

Published: 9 June 2011

\section{References}

1. Miller SD, Turley DM, Podojil JR: Antigen-specific tolerance strategies for the prevention and treatment of autoimmune disease. Nat Rev Immuno 2007, 7(9):665-77.

2. van Duivenvoorde LM, van Mierlo GJ, Boonman ZF, Toes RE: Dendritic cells: vehicles for tolerance induction and prevention of autoimmune diseases. Immunobiology 2006, 211(6-8):627-32. 
3. Morelli AE, Thomson AW: Tolerogenic dendritic cells and the quest for transplant tolerance. Nat Rev Immunol 2007, 7(8):610-21.

4. Chuang JJ, Kleist C, Sandra-Petrescu F, lancu M, Wang D, Opelz G, Terness P: Suppressive dendritic cells as a tool for controlling allograft rejection in organ transplantation: promises and difficulties. Hum Immunol 2008, 69(3):p. 165-73.

5. van Kooten C, Lombardi G, Gelderman KA, Sagoo P, Buckland M, Lechler R, Cuturi MC: Dendritic Cells as a Tool to Induce Transplantation Tolerance: Obstacles and Opportunities. Transplantation 2011, 15(91(1)):2-7.

6. Thomson AW, Robbins PD: Tolerogenic dendritic cells for autoimmune disease and transplantation. Ann Rheum Dis 2008, 67(Suppl 3):90-6, iii.

7. Hilkens CM, Isaacs JD, Thomson AW: Development of dendritic cell-based immunotherapy for autoimmunity. Int Rev Immuno/ 29(2):p. 156-83.

8. Torres-Aguilar H, Blank M, Jara $L$, Shoenfeld Y: Tolerogenic dendritic cells in autoimmune diseases: crucial players in induction and prevention of autoimmunity. Autoimmun Rev 2010, 10(1):8-17.

9. Torres-Aguilar H, Aguilar-Ruiz SR, González-Pérez G, Munguía R, Bajaña S, Meraz-Ríos MA, Sánchez-Torres C: Tolerogenic dendritic cells generated with different immunosuppressive cytokines induce antigen-specific anergy and regulatory properties in memory CD4+ T cells. J Immunol 2010, 184(4):1765-75

10. Luther C, Adamopoulou E, Stoeckle C, Brucklacher-Waldert V, Rosenkranz D, Stoltze L, Lauer S, Poeschel S, Melms A, Tolosa E: Prednisolone treatment induces tolerogenic dendritic cells and a regulatory milieu in myasthenia gravis patients. J Immunol 2009, 183(2):841-8.

11. Harry RA, Anderson AE, Isaacs JD, Hilkens CM: Generation and characterisation of therapeutic tolerogenic dendritic cells for rheumatoid arthritis. Ann Rheum Dis 2010, 69(11):2042-50.

12. Banchereau J, Steinman RM: Dendritic cells and the control of immunity. Nature 1998, 392(6673):245-52.

13. Morelli AE, Thomson AW: Dendritic cells: regulators of alloimmunity and opportunities for tolerance induction. Immunol Rev 2003, 196:125-46.

14. Steinman RM: The dendritic cell system and its role in immunogenicity. Annu Rev Immunol 1991, 9:271-96.

15. Steinman RM, Hawiger D, Nussenzweig MC: Tolerogenic dendritic cells. Annu Rev Immunol 2003, 21:685-711.

16. Tatsumi T, Storkus WJ: Dendritic cell-based vaccines and therapies for cancer. Expert Opin Biol Ther 2002, 2(8):919-28.

17. Figdor CG, de Vries IJ, Lesterhuis WJ, Melief CJ: Dendritic cell immunotherapy: mapping the way. Nat Med 2004, 10(5):475-80

18. Palucka K, Banchereau J, Mellman I: Designing vaccines based on biology of human dendritic cell subsets. Immunity 2010, 33(4):464-78.

19. Palucka K, Ueno H, Fay J, Banchereau J: Harnessing dendritic cells to generate cancer vaccines. Ann N Y Acad Sci 2009, 1174:88-98.

20. Peng JC, Thomas R, Nielsen LK: Generation and maturation of dendritic cells for clinical application under serum-free conditions. J Immunother 2005, 28(6):599-609.

21. Napoletano C, Pinto D, Bellati F, Taurino F, Rahimi H, Tomao F, Panici PB, Rughetti A, Frati L, Nuti M: A comparative analysis of serum and serumfree media for generation of clinical grade DCs. J Immunother 2007, 30(5):567-76.

22. D'Argenio DA, Wilson CB: A decade of vaccines: Integrating immunology and vaccinology for rational vaccine design. Immunity 33(4):p. 437-40.

23. Germain RN: Vaccines and the future of human immunology. Immunity 2010, 33(4):441-50

24. Hackstein H, Thomson AW: Dendritic cells: emerging pharmacological targets of immunosuppressive drugs. Nat Rev Immunol 2004, 4(1):24-34.

25. Turnquist HR, Fischer RT, Thomson AW: Pharmacological modification of dendritic cells to promote their tolerogenicity in transplantation. Methods Mol Biol 2010, 595:135-48.

26. Verginis $\mathrm{P}, \mathrm{Li} H \mathrm{HS}$, Carayanniotis $\mathrm{G}$ : Tolerogenic semimature dendritic cells suppress experimental autoimmune thyroiditis by activation of thyroglobulin-specific CD4+CD25+ T cells. J Immunol 2005, 174(11):7433-9.

27. Min WP, Zhou D, Ichim TE, Strejan GH, Xia X, Yang J, Huang X, Garcia B, White $D$, Dutartre $P$, Jevnikar AM, Zhong R: Inhibitory feedback loop between tolerogenic dendritic cells and regulatory $T$ cells in transplant tolerance. J Immunol 2003, 170(3):1304-12.

28. Huang H, Dawicki W, Zhang X, Town J, Gordon JR: Tolerogenic dendritic cells induce CD4+CD25hiFoxp3+ regulatory $T$ cell differentiation from CD4+CD25-/loFoxp3-effector T cells. J Immunol 2010, 185(9):5003-10.
29. Hill M, Cuturi MC: Negative vaccination by tolerogenic dendritic cells in organ transplantation. Curr Opin Organ Transplant 2010.

30. Stoop JN, Harry RA, von Delwig A, Isaacs JD, Robinson JH, Hilkens CM: Therapeutic effect of tolerogenic dendritic cells in established collageninduced arthritis is associated with a reduction in Th17 responses. Arthritis Rheum 2010, 62(12):3656-65.

31. Quintana FJ, Murugaiyan G, Farez MF, Mitsdoerffer M, Tukpah AM, Burns EJ, Weiner HL: An endogenous aryl hydrocarbon receptor ligand acts on dendritic cells and $T$ cells to suppress experimental autoimmune encephalomyelitis. Proc Natl Acad Sci USA 2010, 107(48):20768-73.

32. van Duivenvoorde LM, Louis-Plence P, Apparailly F, van der Voort El, Huizinga TW, Jorgensen C, Toes RE: Antigen-specific immunomodulation of collagen-induced arthritis with tumor necrosis factor-stimulated dendritic cells. Arthritis Rheum 2004, 50(10):3354-64.

33. van Duivenvoorde LM, Han WG, Bakker AM, Louis-Plence $P$, Charbonnier LM, Apparailly F, van der Voort El, Jorgensen C, Huizinga TW, Toes RE: Immunomodulatory dendritic cells inhibit Th1 responses and arthritis via different mechanisms. J Immunol 2007, 179(3):1506-15.

34. Martin E, Capini C, Duggan E, Lutzky VP, Stumbles P, Pettit AR, O'Sullivan B, Thomas R: Antigen-specific suppression of established arthritis in mice by dendritic cells deficient in NF-kappaB. Arthritis Rheum 2007, 56(7):2255-66.

35. Adorini L: Tolerogenic dendritic cells induced by vitamin $D$ receptor ligands enhance regulatory $\mathrm{T}$ cells inhibiting autoimmune diabetes. Ann N Y Acad Sci 2003, 987:258-61.

36. Marin-Gallen S, Clemente-Casares X, Planas R, Pujol-Autonell I, Carrascal J, Carrillo J, Ampudia R, Verdaguer J, Pujol-Borrell R, Borràs FE, Vives-Pi M: Dendritic cells pulsed with antigen-specific apoptotic bodies prevent experimental type 1 diabetes. Clin Exp Immunol 2010, 160(2):207-14.

37. Nestle FO, Banchereau J, Hart D: Dendritic cells: On the move from bench to bedside. Nat Med 2001, 7(7):761-5

38. Cerundolo V, Hermans IF, Salio M: Dendritic cells: a journey from laboratory to clinic. Nat Immunol 2004, 5(1):7-10.

39. Bluestone JA, Thomson AW, Shevach EM, Weiner HL: What does the future hold for cell-based tolerogenic therapy? Nat Rev Immunol 2007, 7(8):650-4.

40. Rescigno M: Dendritic cells in tolerance induction for the treatment of autoimmune diseases. Eur J Immunol 2010, 40(8):2119-23.

41. Steinman RM: Some active areas of DC research and their medical potential. Eur J Immunol 2010, 40(8):2085-8.

42. Soldevila B, Alonso N, Martínez-Arconada MJ, Morillas RM, Planas R, Sanmartí AM, Martínez-Cáceres EM: A prospective study of T-and Blymphocyte subpopulations, CD81 expression levels on B cells and regulatory CD4(+) CD25(+) CD127(low/-) FoxP3(+) T cells in patients with chronic HCV infection during pegylated interferon-alpha2a plus ribavirin treatment. J Viral Hepat 2010.

43. Rutella S, Danese S, Leone G: Tolerogenic dendritic cells: cytokine modulation comes of age. Blood 2006, 108(5):1435-40

44. Adorini L, Penna G: Induction of tolerogenic dendritic cells by vitamin D receptor agonists. Handb Exp Pharmacol 2009, , 188: 251-73.

45. van Kooten C, Stax AS, Woltman AM, Gelderman KA: Handbook of experimental pharmacology "dendritic cells": the use of dexamethasone in the induction of tolerogenic DCs. Handb Exp Pharmacol 2009, , 188: 233-49.

46. Fischer $\mathrm{R}$, Turnquist HR, Taner $T$, Thomson AW: Use of rapamycin in the induction of tolerogenic dendritic cells. Handb Exp Pharmacol 2009, , 188: 215-32.

47. Anderson AE, Swan DJ, Sayers BL, Harry RA, Patterson AM, von Delwig A, Robinson JH, Isaacs JD, Hilkens CM: LPS activation is required for migratory activity and antigen presentation by tolerogenic dendritic cells. J Leukoc Biol 2009, 85(2):243-50.

48. Penna G, Adorini L: 1 Alpha,25-dihydroxyvitamin D3 inhibits differentiation, maturation, activation, and survival of dendritic cells leading to impaired alloreactive T cell activation. J Immunol 2000, 164(5):2405-11.

49. Fazekasova H, Golshayan D, Read J, Tsallios A, Tsang JY, Dorling A, George AJ, Lechler RI, Lombardi G, Mirenda V: Regulation of rat and human T-cell immune response by pharmacologically modified dendritic cells. Transplantation 2009, 87(11):1617-28

50. Woltman AM, van der Kooij SW, de Fijter JW, van Kooten C: Maturationresistant dendritic cells induce hyporesponsiveness in alloreactive 
CD45RA+ and CD45RO+ T-cell populations. Am J Transplant 2006, 6(11):2580-91.

51. Hackstein H, Taner T, Zahorchak AF, Morelli AE, Logar AJ, Gessner A, Thomson AW: Rapamycin inhibits IL-4-induced dendritic cell maturation in vitro and dendritic cell mobilization and function in vivo. Blood 2003, 101(11):4457-63.

52. Steinbrink K, Wölfl M, Jonuleit $H$, Knop J, Enk AH: Induction of tolerance by IL-10-treated dendritic cells. J Immunol 1997, 159(10):4772-80.

53. Haidinger M, Poglitsch M, Geyeregger R, Kasturi S, Zeyda M, Zlabinger GJ, Pulendran B, Hörl WH, Säemann MD, Weichhart T: A versatile role of mammalian target of rapamycin in human dendritic cell function and differentiation. J Immunol 2010, 185(7):3919-31.

54. Karimi MH, Ebadi P, Pourfathollah AA, Moazzeni M, Soheili ZS, Samiee S: Comparison of Three Techniques for Generation of Tolerogenic Dendritic Cells: siRNA, Oligonucleotide Antisense, and Antibody Blocking. Hybridoma (Larchmt) 2010, 29(6):473-80.

55. Svajger U, Obermajer $\mathrm{N}$, Jeras $\mathrm{M}$ : Novel findings in drug-induced dendritic cell tolerogenicity. Int Rev Immunol 2010, 29(6):574-607.

56. Xiao BG, Huang YM, Link H: Tolerogenic dendritic cells: the ins and outs of outcome. J Immunother 2006, 29(5):465-71.

57. Pulendran $B$, Tang $H$, Manicassamy S: Programming dendritic cells to induce $\mathrm{T}(\mathrm{H}) 2$ and tolerogenic responses. Nat Immunol 2010, 11(8):647-55.

58. Xia CQ, Peng R, Beato F, Clare-Salzler MJ: Dexamethasone induces IL-10producing monocyte-derived dendritic cells with durable immaturity. Scand I Immunol 2005, 62(1):45-54.

59. Xing N, L Maldonado ML, Bachman LA, McKean DJ, Kumar R, Griffin MD: Distinctive dendritic cell modulation by vitamin $\mathrm{D}(3)$ and glucocorticoid pathways. Biochem Biophys Res Commun 2002, 297(3):645-52.

60. Griffin MD, Xing N, Kumar R: Gene expression profiles in dendritic cells conditioned by 1alpha,25-dihydroxyvitamin D3 analog. J Steroid Biochem Mol Biol 2004, 89-90(1-5):443-8.

61. Monti P, Mercalli A, Leone BE, Valerio DC, Allavena P, Piemonti L: Rapamycin impairs antigen uptake of human dendritic cells. Transplantation 2003, 75(1):137-45.

62. Jonuleit H, Schmitt E, Steinbrink K, Enk AH: Dendritic cells as a tool to induce anergic and regulatory T cells. Trends Immunol 2001, 22(7):394-400

63. Kubsch S, Graulich E, Knop J, Steinbrink K: Suppressor activity of anergic T cells induced by IL-10-treated human dendritic cells: association with IL2-and CTLA-4-dependent G1 arrest of the cell cycle regulated by p27Kip1. Eur J Immunol 2003, 33(7):1988-97.

64. Battaglia M, Stabilini A, Roncarolo MG: Rapamycin selectively expands CD4 +CD25+FoxP3+ regulatory T cells. Blood 2005, 105(12):4743-8.

65. Maldonado RA, von Andrian UH: How tolerogenic dendritic cells induce regulatory T cells. Adv Immunol 2010, 108:111-65.

66. Steinbrink K, Graulich E, Kubsch S, Knop J, Enk AH: CD4(+) and CD8(+) anergic $T$ cells induced by interleukin-10-treated human dendritic cells display antigen-specific suppressor activity. Blood 2002, 99(7):2468-76.

67. Cobbold SP, Adams E, Nolan KF, Regateiro FS, Waldmann H: Connecting the mechanisms of T-cell regulation: dendritic cells as the missing link. Immunol Rev 2010, 236:203-18.

68. Francisco LM, Sage PT, Sharpe AH: The PD-1 pathway in tolerance and autoimmunity. Immunol Rev 2010, 236:219-42.

69. Sakaguchi S: Regulatory T cells: key controllers of immunologic selftolerance. Cell 2000, 101(5):455-8.

70. Shevach EM, McHugh RS, Thornton AM, Piccirillo C, Natarajan K, Margulies DH: Control of autoimmunity by regulatory T cells. Adv Exp Med Biol 2001, 490:21-32.

71. Maloy KJ, Powrie F: Regulatory T cells in the control of immune pathology. Nat Immunol 2001, 2(9):816-22.

72. Liu W, Putnam AL, Xu-Yu Z, Szot GL, Lee MR, Zhu S, Gottlieb PA, Kapranov P, Gingeras TR, Fazekas de St Groth B, Clayberger C, Soper DM, Ziegler SF, Bluestone JA: CD127 expression inversely correlates with FoxP3 and suppressive function of human CD4+ T reg cells. J Exp Med 2006, 203(7):1701-11.

73. Sakaguchi S, Miyara M, Costantino CM, Hafler DA: FOXP3+ regulatory $T$ cells in the human immune system. Nat Rev Immunol 2010, 10(7):490-500.

74. Simonetta F, Chiali A, Cordier C, Urrutia A, Girault I, Bloquet S, Tanchot C, Bourgeois C: Increased CD127 expression on activated FOXP3+CD4+ regulatory T cells. Eur J Immuno 2010, 40(9):2528-38.

75. Kang J, Huddleston SJ, Fraser JM, Khoruts A: De novo induction of antigen-specific CD4+CD25+Foxp3+ regulatory $T$ cells in vivo following systemic antigen administration accompanied by blockade of mTOR. $J$ Leukoc Biol 2008, 83(5):1230-9.

76. Munn DH, Sharma MD, Mellor AL: Ligation of B7-1/B7-2 by human CD4+ T cells triggers indoleamine 2,3-dioxygenase activity in dendritic cells. J Immunol 2004, 172(7):4100-10.

77. Penna G, Roncari A, Amuchastegui S, Daniel KC, Berti E, Colonna M, Adorini L: Expression of the inhibitory receptor ILT3 on dendritic cells is dispensable for induction of CD4+Foxp3+ regulatory T cells by 1,25dihydroxyvitamin D3. Blood 2005, 106(10):3490-7.

78. Roncarolo MG, Bacchetta R, Bordignon C, Narula S, Levings MK: Type $1 \mathrm{~T}$ regulatory cells. Immunol Rev 2001, 182:68-79.

79. Roncarolo MG, Gregori S, Battaglia M, Bacchetta R, Fleischhauer K, Levings MK: Interleukin-10-secreting type 1 regulatory T cells in rodents and humans. Immunol Rev 2006, 212:28-50.

80. Weiner HL: Induction and mechanism of action of transforming growth factor-beta-secreting Th3 regulatory cells. Immunol Rev 2001, 182:207-14.

doi:10.1186/1479-5876-9-89

Cite this article as: Naranjo-Gómez et al:: Comparative study of clinical grade human tolerogenic dendritic cells. Journal of Translational Medicine 2011 9:89.

\section{Submit your next manuscript to BioMed Central and take full advantage of:}

- Convenient online submission

- Thorough peer review

- No space constraints or color figure charges

- Immediate publication on acceptance

- Inclusion in PubMed, CAS, Scopus and Google Scholar

- Research which is freely available for redistribution

Submit your manuscript at www.biomedcentral.com/submit
C Biomed Central 